\title{
Pengaruh Metode Demonstrasi Berbantu Patepin Terhadap Hasil Belajar Tema Indahnya Keragaman di Negeriku
}

\author{
Siti Khoiriyah ${ }^{1}$, Rahmat Raiz $^{2}$, Kiswoyo ${ }^{3}$ \\ ${ }^{1,2,3}$ PGSD Fakultas IImu Pendidikan Universitas PGRI Semarang \\ e-mail: stkhoir93931@gmail.com
}

\begin{abstract}
Abstrak
Penelitian ini dilatarbelakangi oleh rendahnya aktivitas belajar yang mempengaruhi rendahnya hasil belajar siswa sehingga tidak mencapai KKM. Tujuan dari penelitian ini untuk mengetahui pengaruh metode demonstrasi berbantu patepin terhadap hasil belajar tema indahnya keragaman di negeriku siswa kelas IV SDN Sukorejo 02 Semarang. Penelitian ini menggunakan metode Pre-eksperimental Designs dengan one group pretest-posttest design. Teknik pengumpulan data menggunakan wawancara, dokumentasi, tes dan observasi. Hasil penelitian menunjukan peningkatan signifikan terhadap hasil belajar siswa dengan rata-rata pretest 57,81 menjadi 76,47 pada posttest. serta $t_{\text {hitung }} 12,96$ lebih besar dari pada $t_{\text {tabel }} 2,021$. Berdasarkan analisis data pada perhitungan ketuntasan belajar pretest-posttest meningkat $50 \%$ siswa yang tuntas. Hal tersebut menunjukkan bahwa metode demonstrasi berbantu patepin memiliki pengaruh dalam meningkatkan hasil belajar indahnya keragaman di negeriku siswa kelas IV SDN Sukorejo Semarang.
\end{abstract}

Kata Kunci: Metode Demonstrasi, Papan Tempel, Hasil.

\begin{abstract}
Research is caused by low learning activities that affect student learning outcomes so they do not reach minimum completeness criteria. This study aims to determine the effect of demonstration method assisted by smart outboard on the learning outcomes the theme of the beauty diversity in my country of class IV elementary school Sukorejo 02 Semarang. Preexperimental research designs with one group pretest-posttest design. Data collection techniques used were interview, documentation, tests, and observations. Research results increased significantly form the average pretest $57,81 \%$ to posttest $76,47 \%$. And $t_{\text {count }} 12,96$ greater then $t_{\text {table }} 2,021$. Besed on data analysis, the completetenss calculation of the pretestposttest learning improve $50 \%$ of students completed. This show that the method of demonstration assisted by patepin hes an impact in raising the learning outcomes of the theme of the beauty of diversity in my country class IV SDN Sukorejo 02 Semarang.
\end{abstract}

Keywords: Demonstration Method, Outboard, Outcomes. 


\section{Pendahuluan}

Pendidikan nasional kita masih menghadapi berbagai macam persoalan. Persoalan itu memang tidak akan pernah selesai, karena substansi yang ditransformasikan selama proses pendidikan dan pembelajaran selalu berada di bawah tekanan kemajuan ilmu pengetahuan, teknologi, dan kemajuan masyarakat. Salah satu persoalan pendidikan kita yang masih menonjol saat ini adalah adanya kurikulum yang silih berganti dan terlalu membebani anak tanpa ada arah pengembangan yang betulbetul diimplementasikan sesuai dengan perubahan yang diinginkan pada kurikulum tersebut. Tidak bisa dipungkiri bahwa perubahan kurikulum selalu mengarah pada perbaikan sistem pendidikan. Perubahan tersebut dilakukan karena dianggap belum sesuai dengan harapan yang diinginkan sehingga perlu adanya revitalisasi kurikulum (Osa ,2013).

Sejak diberlakukannya peraturan Kurikulum 2013 setiap sekolah wajib menggunakan Kurikulum 2013 yang pembelajaranya menggunakan tema. Paraturan pembelajaran tematik di sekolah dasar tertuang dalam lampiran Permendikbud no. 67 tahun 2013. Tema merupakan wadah atau wahana untuk mengenalkan berbagai konsep materi kepada anak didik secara utuh (Rusman, 2017: 353). Dalam pembelajaran K-13 penyampaian konsep materi akan mudah dipahami oleh siswa dan dapat mempersingkat waktu pembelajaran. Oleh karna itu, pendidik harus pandai-pandai menelola pembelajaran di dalam kelas. Seperti penggunaan metode, media, dan strategi yang tepat serta sesuai dengan tujuan pembelajaran yang telah ditetapkan. Kurikulum berfungsi sebagai pedoman dalam pelaksanaan kegiatan pendidikan di sekolah bagi pihak-pihak yang terkait, baik secara langsung maupun tidak langsung, seperti pihak guru, kepala sekolah, pengawas, orangtua, masyarakat dan pihak siswa itu sendiri, dalam mengimplementasikan kurikulum 2013 (Kurniawan ,2013).

Peranan guru bukan lagi sebagai sumber belajar melainkan, sebagai fasilitator yang membantu dan mengarahkan siswa untuk menemukan sendiri. Selain itu guru juga harus mampu menyisipkan nilai-nilai yang ada dalam $\mathrm{K}-13$ melalui proses pengajaran dan pembelajaran yang di lakukan dalam maupun di luar kelas. Yang mana proses kegiatan pembelajaran berpusat pada siswa atau student centered. Menurut arifuddin, (2017: 167) student centered merupakan bahwa aktivitas dan peran siswa lebih banyak dari pada guru.

Muatan pelajaran yang tertuang dalam tema diantaranya adalah IPA, Bahasa Indonesia, dan SBDP, dan IPS. Sehingga pembelajaran harus didesain menarik untuk meningkatkan pemahaman belajar siswa. Dalam implementasi Kurikulum 2013 dalam pembelajaran, akan melatih siswa dalam mengembangkan kognitif, psikomotor, afektif, serta siswa dapat memahami konsep yang mereka bangun sendiri.

Berdasarkan hasil wawancara dengan Ibu Puji Priani S.Pd.SD di kelas IV SDN Sukorejo 02 Semarang bahwa "siswa kurang memperhatikan pembelajaran dan asik bermain dengan teman sebangku sehingga mengakibatkan siswa kurang memahami materi dan hasil belajar siswa rendah". KKM pembelajaran yang ditetapikan di SDN Sukorejo 02 Semarang yaitu 65. Dari hasil observasi didapatkan nilai ulangan harian, dari 42 siswa yang belum mencapai KKM sebanyak 20 siswa atau $48 \%$.

Berdasarkan permasalahan diatas, diperlukan solusi untuk memperbaiki pembelajaran untuk meningkatkan pemahaman dan hasil belajar siswa. Dalam hal ini kemampuan dan ketepatan guru dalam memilih metode dan media pembelajaran sangat mempengaruhi kualitas dan keberhasilan sebuah pembelajaran yang akan dilakukan. Oleh sebab itu, pembelajaran tematik harus dilakukan dengan menerapkan metode pembelajaran yang relevan dengan media yang tepat dan memberikan pengalaman langsung yang sesuai dengan materi. Salah satu metode pembelajaran yang dapat digunakaan dalam pembelajaran adalah metode demonstrasi.

Demonstrasi adalah salah satu kegiatan mempertunjukkan jalanya suatu proses, reaksi atau cara berkerjanya suatu alat oleh seorang demonstrator di khalayak (Suyono dan Hariyanto, 2015: 105). Metode demonstrasi mempunyai tujuan untuk mengajak peserta didik aktif dalam pembelajaran dan belajar langsung, serta saling bertukar informasi dengan kelompok dan berkompetisi dengan teman. Dalam metode demonstrasi penggunaan alat peraga dapat digunakan sebagai media pendukung dalam pembelajaran. Menurut Nana Sudjana (2010:83) "metode demonstrasi adalah suatu metode mengajar memperlihatkan bagaimana jalannya suatu proses terjadinya sesuatu." Oleh karena itu metode demonstrasi merupakan metode mengajar yang sangat efektif, sebab membantu para peserta didik untuk mencari jawaban degan usaha sendiri berdasarkan fakta yang dilihat (Anwar ,2016). 
Metode demonstrasi metode penyajian pelajaran dengan memperagakan dan mempertunjukkan kepada siswa tentang suatu proses, situasi atau benda tertentu, baik sebenarnya atau hanya sekadar tiruan (Wina Sanjaya 2006:152). Sebagai metode penyajian, demonstrasi tidak terlepas dari penjelasan secara lisan oleh guru. Walaupun dalam proses demonstrasi peran siswa hanya sekedar memperhatikan, akan tetapi demonstrasi dapat menyajikan bahan pelajaran lebih konkret. Dalam strategi pembelajaran, demonstrasi dapat digunakan untuk mendukung keberhasilan strategi pembelajaran ekspositori dan inkuiri.Penggunaan metode demonstrasi diharapkan dapat meningkatkan hasil belajar siswa dan proses belajar mengajar menjadi lebih aktif sehingga pembelajaran tidak hanya didominasi oleh guru melainkan juga melibatkan siswa. Dengan demikian siswa akan terlibat aktif sehingga diharapkan konsep perubahan benda yang diajarkan oleh guru dapat dipahami oleh siswa dengan baik (Sartini , 2014).

Kelebihan Metode demonstrasi yaitu: (1) siswa akan memperoleh gambaran yang lebih jelas mengenai proses sesuatu yang telah didemonstrasikan, ( 2 ) Perhatian siswa akan lebih mudah dipusatkan pada hal - hal yang penting yang sedang dibahas, ( 3 ) bila siswa turut aktif melakukan demonstrasi, maka siswa akan memperoleh pengalaman praktek untuk mengembangkan kecakapan dan keterampilan, ( 4 ) dapat mengurangi kesalahan pengertian antara siswa dan guru bila di bandingkan dengan ceramah dan tanya jawab, karena dengan demonstrasi siswa akan dapat mengamati sendiri proses dari sesuatu (Busoso, 2014).

Adapun kelebihan Metode Demonstrasi yang dikemukakan oleh Damawang, dkk (2008: 119) sebagai berikut: Memberikan gambaran nyata yang memperjelas suatu pembahasan di dalam kegiatan belajar mengajar, Memberikan peluang kepada peserta didik untuk memperoleh pengalaman secara langsung, mengembangkan kecakapannya karena terlibat langsung dalam proses peragaan (Nawir,2015).

Sedangkan kekurangan metode demonstrasi adalah: 1) Metode ini memerlukan keterampilan guru secara khusus, karena tanpa ditunjang dengan hal itu, pelaksanaan demonstrasi akan tidak efektif, 2) Fasilitas seperti peralatan, tempat, dan biaya yang memadai tidak selalu tersedia dengan baik, 3) Demonstrasi memerlukan kesiapan dan perencanaan yang matang di samping memerlukan waktu yang cukup panjang, yang mungkin terpaksa mengambil waktu atau jam pelajaran lain (Suryani ,2015).

Alat peraga membantu guru dalam menciptakan kondisi lingkunan belajar yang efektif (Harumsari, 2018: 521) sehingga dengan media dapat menarik perhatian siswa dalam pembelajaran dan belajar dengan mandiri. Salah satu pemebelajaran yang membutuhkan alat peraga yaitu pembelajaran tematik.

Dari permasalahan diatas maka peneliti mencoba melakukan penelitian yang berjudul "pengaruh metode demonstrasi berbantu media patepin terhadap hasil belajar tema indahnya keragaman di megeriku SDN Sukorejo 02 Semaran. Dengan tujuan agar mengetahui seberapa besar pengaruh penggunaan metode demonstrasi dengan berbantu media patepin terhadap hasil belajar.

\section{Metode}

Penelitian dilakukankan di kelas IV SDN Sukorejo 02 Semarang semester 2 tahun pajaran 2018/2019. Penelitian ini menggunakan penelitian Pre-eksperimental, dengan one group pretest-posttest design.

$$
Q_{1} \times Q_{2}
$$

Gambar 1. Rancangan Penelitian

Keterangan:

$\mathrm{Q}_{1}=$ nilai pretest (sebelum diberi perlakuan)

$\mathrm{Q}_{2}=$ nilai posttest (setelah diberi perlakuan)

$\mathrm{X}=$ tritment yang diberikan (Sugiyono, $2017: 111$ )

Populasi dalam penelitian ini adalah seluruh siswa kelas IV SDN Sukorejo 02 Semarang. Dengan teknik sampling total dengan jumlah 42 siswa, yang terdiri dari 21 siswa laki-laki dan 21 siswa perempuan. Sugiyono (2018: 140), menyatakan bahwa sampling tota dengan ketentuan 
dimana pengambilan sampel seluruh anggota populasi dijadikan sempel semua. Apabila penelitian dilakukan dengan populasi dibawah 100 .

Teknik pengumpulan data yang digunakan dalam penelitian ini adalah berupa tes dan non tes. Teknik tes dipergunakan untuk mengukur hasil belajar (kognitif) dengan penggunaan metode pembelajaran demonstrasi berbantu media patepin. Jenis tes dalam penelitian ini adalah soal pilihan ganda yang diberikan pada saat pelaksanaan pretest dan posttest. Arikunto (2017: 33) mengatakan bahwa tes adalah alat atau prosedur yang digunakan untuk mengetahui atau mengukur sesuatu dalam suasana, dengan cara dan aturan-aturan yang sudah di tentukan.

Sedangkan teknik non tes berupa wawancara, observasi, dan dokumentasi. Wawancara dilakukan untuk memperoleh daftar nama siswa, permasalahan, serta memperoleh data nilai ulangan harian tema 4: "Berbagai Pekerjaan" pada saat observasi. Menurut Sugiyono (2017: 194) wawancara digunakan sebagai teknik pengumpulan data apabila peneliti ingin melakukan studi pendahuluan untuk melakukan permasalahan yang harus diteliti, dan apabila peneliti ingin mengetahui hal-hal dari responden yang lebih mendalam dan jumlah respondennya sedikit/ kecil.

Teknik analisis data yang digunakan penelitian ini yaitu teknik analisis data awal (data pretest), teknik analisis data akhir (data posttest), uji-t dengan tingkat kesukaran $5 \%$, dan uji ketuntasan belajar individu, dan uji ketuntasan belajar kelompok. Uji ketuntasan belajar data yang dibandingkan adalah data sebelum dan sesudah treatment, dimana treatment disini adalah motode demonstrasi berbantu media patepin (papan tempel pintar).

\section{Hasil Penelitian Dan Pembahasan}

Sebelum dilaksnakan penelitian, peneliti terlebih dahulu melakukan kegiatan studi pendahuluan untuk mengetahui permasalahan-permasalahan yang terjadi. Studi pendahuluan dilakukan pada tanggal 25 oktober 2018. Berdasarkan hasil studi pendahuluan ini, diketahui bahwa permasalahan yang didapat yaitu rendahnya nilai hasil belajar siswa. Terbukti dari nilai ujian harian siswa yang belum mencapai ktiteria ketuntasan minimum (KKM). Terdapat 48\% siswa yang masih belum tuntas.

Berdasarkan uji coba instrumen dengan jumlah soal pilihan ganda 50 soal. Dari soal uji didapatkan 25 soal pilihan ganda yang digunakan untuk soal pretest-posttest. Pretest merupakan test awal yang digunakan untuk mengetahui kemampuan awal siswa sebelum diberikan perlakuan metode demonstrasi berbantu media patepin. Posttest merupakan test akhir untuk mengetahui kemampuan akhir siswa sesudah diberikan perlakuan metode demonstrasi berbantu media patepin.

Berikut adalah data nilai yang diperoleh dari hasil nilai pretest ( sebelum diberi perlakuan dengan metode pembelajaran Demonstrasi berbantu media petepin) dan nilai posttest ( sesudah diberi perlakuan dengan metode pembelajaran demonstrasi berbantu media patepin) hasil belajar tema indahnya keragaman di negeriku kelas IV SDN Sukorejo 02 Semarang yang disajikan dalam bentuk table di bawah ini.

Table 1. Data Nilai Pretest dan Posttest

\begin{tabular}{c|c|c}
\hline Keterangan & Pretest & Postest \\
\hline Nilai Tertinggi & 88 & 96 \\
Nilai Terendah & 32 & 44 \\
Rata-rata & 57,81 & 76.47 \\
\hline \multicolumn{2}{|c}{ Sumber: Data Hasil Penelitian 2019 }
\end{tabular}

Berdasarkan Tabel 1 diatas dapat dilihat bahwa selisih nilai sebelum diberi perlakuan dan sesudah diberi perlakuan. nilai pretest tertinggi 88 , sedangkan terendah 32 , dengan nilai rata-rata kelas sebesar 57,81. Sedangkan nilai posttest yang diperoleh pada akhir pembelajaran dan setelah diberikan perlakuan dengan metode pembelajaran demonstrasi berbantu media patepin mengalami kenaikan seperti terlihat pada tabel diatas, nilai posttest tertinggi adalah 96 , dan terendah 44 , dengan nilai rata-rata 76,47 . Selain itu, peningkatan hasil belajar pretest dan posttest dapat dilihat pada grafik dibawah ini: 


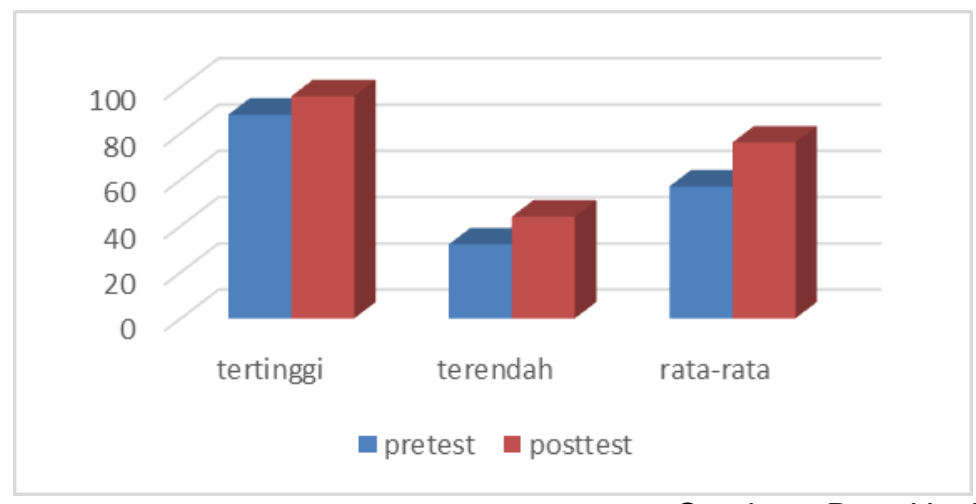

Sumber : Data Hasil penelitian 2019

Gambar 2. Grafik Hsil Belajar

Hal ini dikarenakan pada pembelajaran menggunakan metode demonstrasi berbantu media patepin, menjadikan siswa lebih tertarik karena pembelajaran yang lebih nyata dan siswa akan lebih paham. Hal ini dikarenakan setiap siswa dapat mendemonstrasikan materi yang dipelajari. Sesuai dengan pendapat Suyono \& Haryanto (2015:105) bahwa: Demonstrasi adalah salah satu kegiatan mempertunjukkan jalanya suatu proses, reaksi atau cara berkerjanya suatu alat oleh seorang demonstrator di khalayak.

Penggunaan media patepin baik secara kelompok maupun individu, mengajak siswa untuk berfikir kritis dalam menjawab soal dengan cara mendemonstrasikan untuk mengetahui jawaban. Dengan kegiatan kelompok dapat menumbuhkan rasa kerjasama antar kelompok, siswa menjadi aktif, dan mendorong daya saing atau kompetisi yang terjadi antar kelompok.Serta dapat menguji hasil belajar siswa secara berkelompok untuk menjawab soal dan menyusun jawaban yang masih dalam keadaan acak. Kegiatan berkelompok dalam pembelajaran ini dapat menumbuhkan rasa solidaritas serta kerjasama antar kelompok.

Strategi demonstrasi juga memiliki beberapa kekurangan, antara lain (Huda, 2013: 233234): 1) ia mengharuskan ketrampilan guru secara khusus; 2) tidak tersedianya fasilitas-fasilitas pendukung, seperti peralatan, tempat, dan biaya yang memadai disetiap kelas; 3) memerlukan kesiapan dan perencanaan yang matang di samping waktu yang cukup panjang; 4) kesulitan siswa terkadang untuk melihat dengan jelas benda yang akan dipertunjukan; 5) tidak semua benda dapat didemonstrasikan; dan 6) sukar dimengerti jika didemonstrasikan oleh guru yang kurang menguasai materi.

Penggunaan media dalam pembelajaran juga penting dalam pembelajaran. diantaranya: 1) memudahkan siswa dalam memahami materi pembelajaran, 2) aspek materi mudah dipahami, konkrit medianya dan konkrit pemahamannya, 3) memiliki waktu yang lebih banyak dalam mempelajari materi dan menambah materi yang relevan, 4) membangkitkan minat belajar siswa, 5) multi-aktif, 6) lebih mendalam dan utuh (Satrianawati, 2018:9).

Berdasarkan penelitian yang dilakukan peneliti untuk mengetahui pengaruh motode demonstrasi berbantu patepin terhadap hasil belajar tema indahnya keberagamandi negeriku kelas IV SDN Sukorejo 02 Semarang, analisis menggunakan uji ketuntasan belajar diperoleh hasil sebagai berikut:

Tabel 2. Data Uji Ketuntasan Hasil Pretest Dan Posttest.

\begin{tabular}{cccc}
\hline Keterangan & Pretest & Postest & Nilai ketuntasan \\
\hline Rata-rata & 57,81 & 76,48 & $\geq 65$ \\
\hline Jumlah siswa yang tuntas & 15 & 36 & $\geq 70$ \\
\hline Ketuntasan klasikal (\%) & $36 \%$ & $86 \%$ & \\
\hline Jumlah siswa yang belum tunas & 27 & 6 & \\
\hline Belum tuntas klasikal (\%) & $64 \%$ & $14 \%$ & Sumber: Data Hasil Penelitian 2019
\end{tabular}

Data pretest dan posttest ketuntasan klasikal dapat dilihat pada gambar diagram lingkaran, guna mempermudah dalam mengetahui perbandingannya sebagai berikut: 


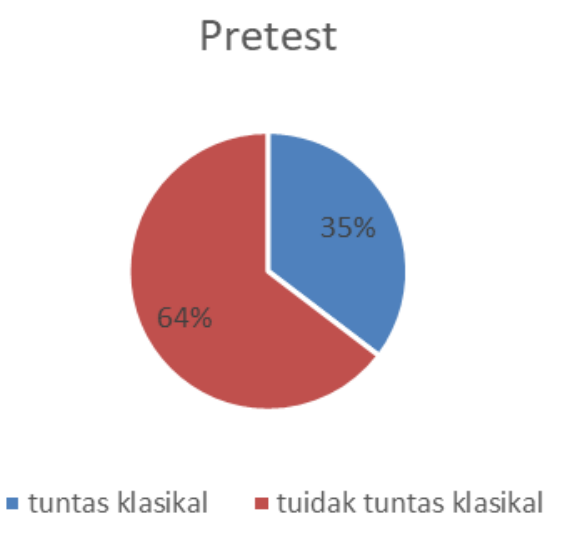

Sumber: Data Hasil Penelitian 2019.

Gambar 3. Diagram Ketuntasan Klasikal Hasil Belajar

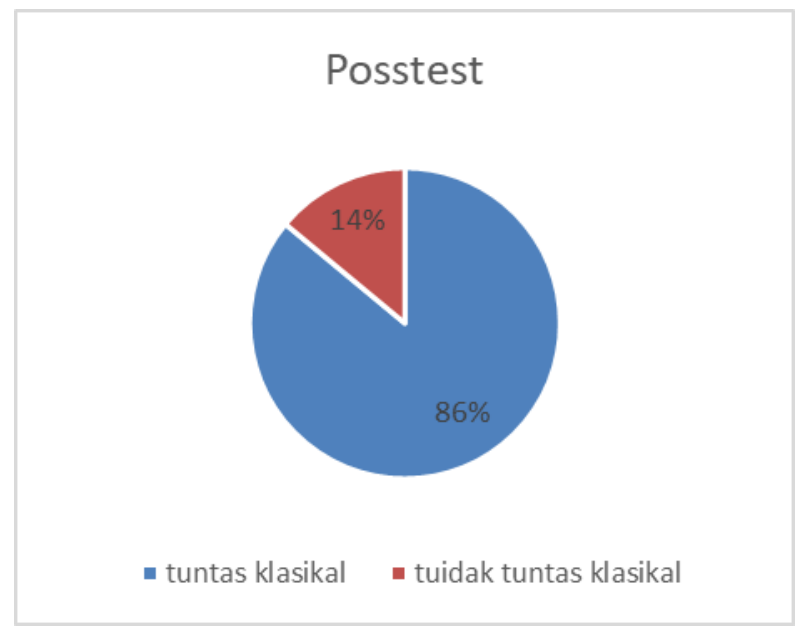

Sumber: Data Hasil Penelitian 2019

Gambar 4. Diagram Ketuntasan Klasikal Hasil Belajar

Dari hasil data nilai pretest dan posttest tersebut kemudian di uji hipotesis dengan menggunakan uji-t sebagai berikut:

Tabel 3. Data Hasil Pretest Dan Posttest Dengan Menggunakan Uji Beda.(Arikunto, 2010:349)

\begin{tabular}{lll} 
Keterangan & Pretest & Postest \\
\hline Nilai Tertinggi & 88 & 96 \\
\hline Nilai Terendah & 32 & 44 \\
\hline Rata-rata & 57,81 & 76,48 \\
\hline $\mathrm{Md}$ & 20,19 \\
\hline $\mathrm{N}(\mathrm{n}-1)$ & 1722 & \\
\hline $\mathrm{T}_{\text {hitung }}$ & 12,96 \\
\hline $\mathrm{t}_{\text {tabel }}$ & 2,021 & \\
\hline & \multicolumn{3}{c}{ Sumber: Data Hasil Penelitian 2019}
\end{tabular}

Berdasarkan Tabel 3 diatas dengan hasil analisis perhitungan uji-t diperoleh $t_{\text {hitung }}$ sebesar 12,96. Sedangkan $t_{\text {tabel }}$ dengan taraf signifikan $5 \%$ dan $d b=n-1(42-1)$ adalah 2,021 . $\mathrm{Hal}$ ini bearti, $\mathrm{t}_{\text {hitung }}>\mathrm{t}_{\mathrm{tabe}}$, sehingga Ho ditolak dan Ha diterima. Jadi hasil prestasi belajar posttest lebih baik dari pada hasil prestasi belajar pretest.

Dengan perbedaan rata-rata dan uji-t pretest dan posttest. Kedua data tersebut menunjukkan bahwa hasil rata-rata posttest lebih baik dari pada pretet. Perbedaan prestasi belajar tersebut tentunya dipengaruhi oleh penerapan metode demonstrasi berbantu media 
patepin di kelas IV SDN Sukorejo 02 Semarang. Dari penjelasan diatas maka penelitian telah membuktikan bahwa bahwa metode demonstrasi berbantu media patepin berpengaruh terhadap prestasi belajar siswa tema indahnya keragaman di negeriku SDN Sukorejo 02 Semarang.

\section{Kesimpulan}

Berdasarkan hasil penelitian dan pembahasan dapat disimpulkan bahwa ada pengaruh dalam penerapan metode demonstrasi berbantu media patepin (papan tempel pintar) terhadap hasil belajar tema 7 indahnya keragaman di negeriku kelas IV SDN Sukorejo 02 Semarang. Dibuktikan pada hasil perhitungan, yang menunjukkan adanya perbedaan rata-rata pretest sebesar 57,81 dan nilai posttest sebesar 76,48 yang menunjukkan bahwa nilai posttest lebih baik dari nilai pretest. Serta perhitungan ketuntasan belajar siswa secara klasikal posttest $>$ pretest sebesar $86 \%>36 \%$ yang mengalami kenaikan sebesar $50 \%$, dengan uji-t yang menunjukkan bahwa $t_{\text {hitung }} 12,96>\mathrm{t}_{\text {tabel }}$ 2,021 kemudian data hipotesis diterima. Bahwa adanya pengaruh metode demonstrasi berbantu media patepin terhadap hasil belajar siswa SDN Sukorejo 02 Semarang.

\section{Daftar Pustaka}

Arifudin, Ahmad. 2017. Pengaruh Metode Demonstrasi dengan Alat Peraga Jembatan Garis Bilangan Terhadap Hasil Belajar Matematika Materi Bilangan Bulat. Jurnal pendidikan guru. Vol 4 (2), 14

Arikunto, Suharsimi. 2010. Prosedur Penelitian Suatu Pendekatan Praktik. Jakarta: Rineka Cipta.

Suryani ,Hj (2015). Penggunaan Metode Demonstrasi Untuk Meningkatkan Hasil Pembelajaran Ipa Di Kelas Iv Sekolah Dasar. Jurnal Program Studi Pendidikan Guru Sekolah Dasar FKIP UNTAN, Pontianak.

. 2009. 2012. Dasar-Dasar Evaluasi Pendidikan. Jakarta: Bumi Aksara.

Anwar Fransiskus (2016). Penggunaan Metode Demonstrasi Untuk Meningkatkan Hasil Pembelajaran Ipa Di Kelas Iv Sekolah Dasar . Jurnal FKIP UNTAN, Pontianak.

Busoso ,Mersilia (2014). Penerapan Metode Demonstrasi Dapat Meningkatkan Hasili Belajar Siswa Pada Materi Kenampakan Bumi di Kelas IV SDN No. 2 Pangalasiang . Jurnal Kreatif Tadulako Online Vol. 3 No. 4 ISSN 2354-614X

Harumsari. 2018. Pengaruh Metode Demonstrasi Dengan Menggunakan Alat Peraga Terhadap Hasil Belajar Fisika Materi Hukum li Newton Pada Kelas X Di Sma Negeri 1 Pangkalan Lampam Kabupaten Ogan Komering llirpengaruh. Palembang: Universitas PGRI Palembang.

Huda, Miftahul. 2013. Model-model Pengajaran dan Pembelajaran. Yogyakarta: Pustaka Pelajar.

Kurniawan ,Otang (2013). Penerapan Kurikulum 2013 Dalam Meningkatkan Keterampilan, Sikap, Dan Pengetahuan . Jurnal Primary Program Studi Pendidikan Guru Sekolah Dasar Fakultas Keguruan dan IImu Pendidikan Universitas Riau Volume 6 Nomor 2 Oktober 2017 | ISSN: 2303-1514

Nawir (2015). Penerapan Metode Demonstrasi Untuk Meningkatkan Keterampilan Melukis Peserta Didik Kelas Xii Ipa 3 Sma Negeri 1 Donri Donri Kabupaten Soppeng . Jurnal Penelitian dan Evaluasi Pendidikan Volume 1, No. 12015.

Osa ,Siti (2013). Analisis Konsep Dan Implementasi Kurikulum 2013 . Jurnal PPKn \& Hukum Vol. 12 No. 1 April 2017 
JP2, Vol 2 No 1, Tahun 2019

p-ISSN : 2614-3909 e-ISSN : 2614-3895

Permendikbud. 2013. Menteri Pelatihan Guru, Implementasi Kurikulum 2013. Jakarta.

Rusman. 2017. Belajar dan Pembelajaran Berorientasi Standar Proses Pendidikan. Jakarta. Karisma Putra Utama.

Sartini (2014). Penerapan Metode Demonstrasi Dalam Pemelajaran IImu Pengetahuan Alam Untuk Meningkatkan Hasil Belajar Siswa Sekolah Dasar. Jurnal Pendidikan Guru Sekolah Dasar FKIP Untan, Pontianak

Satrianawati. 2018. Media \& Sumber Belaja. Yogyakarta: Deepublish.

Sudjana, Nana \& Ahmad Rivai. 2005. Media pengajaran. Bandung. Sinar baru

Sugiyono. 2017. Metode Penelitian Pendidikan Kuantitatif, Kualitatif, dan R\&D. Bandung: Alfabeta.

-, 2018. Metode Penelitian Pendidikan Kuantitatif, Kualitatif.. Bandung: Alfabeta.

Suyono dan Hariyanto. 2015. Implementasi Belajar dan Pembelajaran. Bandung. Remaja Rosdakarya. 